Studia Anglica Posnaniensia 48, 2-3, 2013

doi: 10.2478/stap-2013-0008

\title{
COMING TO TERMS WITH A PAGAN PAST: THE STORY OF ST ERKENWALD
}

\author{
STEFAN SCHUSTEREDER
}

Universität Bonn, Germany

\begin{abstract}
The poem of St Erkenwald and his encounter with the body of a pagan judge preserved in a tomb underneath St Paul's Cathedral has never provoked an intense scholarly discussion. During the past two decades, however, the poem has altogether lost the scarce attention it used to receive. This is surprising in regards to its outstanding quality but also because of a number of peculiar characteristics the text has in comparison with other works written during the Middle Ages. Arguing for the importance of the historical details provided by the poem, my article takes a number of these peculiarities into account and suggests a new reading of the poem. In this approach, I do not dismiss the major topics of the earlier scholarly discussions, mostly focused on the poem's theological and stylistic topics or its presumed sources. My article rather presents an additional reading from the perspective of a literary history, thus arguing that the poem of St Erkenwald can be placed within a discourse tradition to which a number of earlier authors contributed, the most famous among them being the Venerable Bede. While the poem addresses a variety of theological and stylistic topics and is of course influenced by its contemporary religious and social developments, it also contributes to one of the fundamental problems of English identity in the Middle Ages: coming to terms with a pagan origin.
\end{abstract}

Keywords: St Erkenwald, History of the English, Pagan Ancestry, Middle English Poetry, $14^{\text {th }}$ and $15^{\text {th }}$ century literature

\section{Introduction}

The poem of Saint Erkenwald and the story of his encounter with the body of a pagan judge preserved in a tomb underneath St Paul's Cathedral in London has never really provoked an intense scholarly discussion. During the past two decades the poem has altogether lost the scarce scholarly attention it used to re- 
ceive. This is surprising, not only in regard to its outstanding quality but also because of a number of peculiar, possibly even singular characteristics the text has in comparison with other works written during the Middle Ages. The following paper will take a number of these peculiarities into account and suggest a reading of the poem which goes beyond earlier scholarly discussions which have mostly focused on the poem's theological and stylistic topics or its presumed sources. This contribution presents a postcolonial reading of a Middle English poem that deals, among other aspects, with a very fundamental problem of the English throughout their insular history, i.e. their pagan past. The arrival of the Germanic gentes and the conquest of the Christian Britons by these pagan people from the Continent as well as the Christianization of the Anglo-Saxons a few centuries later had a significant influence on historiography, literature and the development of a collective memory during the English Middle Ages. The dilemma of authors in Christian medieval England explaining the conquest of Christian Britain by their pagan Anglo-Saxon ancestors was nourished by continuous changes in the ethnic composition of the Island resulting from invasions and migrations. The struggle for religious dominance during the Viking raids and for political survival during the Norman Conquest influenced the shaping of English history and the collective memory of the people. I will demonstrate in the course of this contribution that the poem of St Erkenwald can be placed within a discourse tradition which is strongly influenced by the necessity of a shared history and memory. It had been productive for many centuries before the poem was written and a number of earlier authors had contributed to it, the most famous among them being the Venerable Bede. While the poem addresses a variety of theological and stylistic topics and is, of course, influenced by its contemporary religious and social developments, it also contributes to one of the central issues of English identity in the Middle Ages: coming to terms with a pagan origin. By contextualizing this aspect of the poem of St Erkenwald with the scholarly discussion about its presumed authorship and origin, I will further argue for the relevance of the issue of the pagan past among the ruling elites of late fourteenth and early fifteenth century England.

\section{The poem of St Erkenwald}

The poem survives in one medieval manuscript, British Museum Ms. Harley 2250 , which originally consisted of 88 folios; ${ }^{1}$ today, the volume consists of 111 leaves, a flyleaf and two end papers which are modern additions, presumably 1 Harley 2250 contains one further unrelated manuscript that was bound together with the one
containing the Erkenwald poem. 
added during the rebinding in 1881 (Peterson 1977: 7). ${ }^{2}$ The poem, titled De Erkenwaldo and De Sancto Erkenwaldo, covers ff. 72b-75a of the manuscript (Peterson 1977: 1). ${ }^{3}$ The folios 1 until 87 are written in the same hand, with some minor exceptions, indicating that the Erkenwald poem was put into writing by the same scribe as the other texts contained in the manuscript (Peterson 1977: 2). ${ }^{4}$ Ms. Harley 2250 has been dated to the last quarter of the fifteenth century and is a collection of various, mostly religious, poems including parts of the South English Legendary, a portion of the stanzaic Life of Christ and pieces of text about a number of other English saints (Gollancz 1922: v).

Whereas the date of composition of British Museum Harley 2250 has not been the subject of controversy, establishing a date of composition for the poem has not been as simple. While earlier research and earlier editions of the manuscript, including the edition by Isreal Gollancz from 1922, traditionally dated the composition of the poem to $1386 \mathrm{AD}$, the latest edition by Clifford Peterson argued for a later date of composition in the late fourteenth or early fifteenth century (Peterson 1977: 11-15). ${ }^{5}$ Gollancz based his claim on the celebration of St Erkenwald in London in 1386, adding that the text could also have been part of the preparations of the celebrations, which would indicate a date of composition a few years earlier (Gollancz 1922: 1vi). ${ }^{6}$ Based on the alliterative nature of the poem, Peterson agreed that the composition predates the date of composition of the manuscript; the period of the Alliterative Revival, which the poem belongs to, had concluded by the mid-fifteenth century (Peterson 1977: 12). The language used in the poem indicates a date of composition probably slightly later than 1386 but no later than 1420, which at least limits the possible time period of the composition (Peterson 1977: 15). The poem was also assigned to

2 In his discussion, Peterson followed the inscription in the manuscript claiming it consists of 88 folia; when referring to British Museum Harley 2250 he excluded the last leaves which he claimed to be later additions. Furthermore, he claimed that the date can be fixed precisely based on a colophon on Folio 64v which reads: "Expicit Speculum Xpiani anno do $\mathrm{m}$ ccc lxxvi". There is no indication that the colophon was a later addition to the manuscript; the year of 1477 as the date of composition agrees roughly with earlier discussions about the date of a watermark preserved at the end of the volume, see Peterson (1977: 2).

3 For a detailed discussion of the characteristics of British Museum Harley 2250, see Peterson (1977: 1-11).

4 Inscriptions in the manuscript indicate that it originally consisted of 88 folia; the Harley Catalogue, written in 1759, describes the manuscript as one with 111 folia. Clifford Peterson claimed a later addition of 24 folia to the manuscript, presumably during the late seventeenth or the early eighteenth century. The folia following folio 88 are written in a fifteenth century hand, see Peterson (1977: 2).

5 The earliest edition was published by Carl Horstmann in his collection of Old English legends in 1881, see Horstmann (1881). Later editions were published by Israel Gollancz (1922) and by Ruth Morse (1975). The latest edition by was published by Peterson (1977). Gollancz's claim was shared by Henry Savage, see (Savage 1926: 1xxvi). 
the tradition of a new interest and direction in historiography which began during the $12^{\text {th }}$ century and continued until the late Middle Ages (Otter 1994: 387). An identification of the author could, of course, help to arrive at a more precise date of composition.

In this regard, it has been claimed that the author was the same person who composed the poems Pearl, Patience, Cleanness and Sir Gawain and the Green Knight (Peterson 1977: 15). ${ }^{7}$ This assertion has been questioned regularly in the scholarly discussion for two main reasons: first, the author of the Pearl-group, like the author of the St Erkenwald poem, remains unknown. Second, the manuscripts containing the Pearl-group and the story of St Erkenwald are different from each other (Peterson 1974: 49). Larry Benson concluded that the Erkenwald manuscript is not only significantly later than the Pearl manuscript, but that it is also written in a different dialect and in a different hand; there seems to be hardly any evident congruency between the writing of the Erkenwald poem and of the poems of the Pearl-group with the exception of the wording in some lines (Benson 1965: 395-96). The similarities in wording or even the occurrence of similar lines in poems from both manuscripts indicate a common tradition instead of a common author; this argument is supported by similarities in style and meter (Benson 1965: 397-98). ${ }^{8}$ As long as the question about the common authorship of these texts remains unanswered, Peterson suggested that "the a priori assumption must be that there were five poets" (Peterson 1977: 18-19).

One particular claim about the authorship of the Erkenwald poem has caused a lively discussion among scholars: the name of Thomas masse esquir appears in the bottom centre of folio $13 \mathrm{r}$ of the manuscript; it is written in a late $15^{\text {th }}$ - or early $16^{\text {th }}$-century hand, using a brown ink, similar to the one used for the text on the leaf (Peterson 1977: 9). The name appears again in different, presumably later hands, with different types of ink on other folios of the manuscript. This raised the question if the Erkenwald poet could possibly be linked with a member of the Massey family in Cheshire (Peterson 1977: 9). ${ }^{9}$ The connection between the inscriptions in Harley 2250 and a maister Massy mentioned in a short

7 These texts are preserved in British Library Ms. Cotton Nero A. x. art. 3. The theory of a common author between the Pearl-group and the poem of St Erkenwald was, for example, argued for in Savage (1926) on the basis of similarities in vocabulary and expressions as well as the shared religious outlook.

8 Benson also claimed that the identification of the Erkenwald poet with the author of the Pearl-group poems had misled the Erkenwald research in the past, because scholars only focused on the similarities between these poems instead of providing detailed discussions of the Erkenwald poem itself, see Benson (1965: 405). He concluded that the discussion about the Erkenwald poem as an individual text, therefore, had yet to begin.

9 For the history of the Massey family as well as the different spellings of their name, see Peterson (1977: 9, 20-23). The claim for the connection between Massey and the Erkenwald poem was already made in (Peterson 1974: 53). 
poem by Thomas Hoccleve was made in 1971 in an article by David FarleyHills (Nolan and Farley-Hills 1971: 296). Hoccleve's poem and some of his letters connect maister Massy with the House of Lancaster, particularly with John of Lancaster, during the years between the composition of Hoccleve's Regiment of Princes in 1411 and 1412, and 1414, when John became Duke of Bedford (Nolan and Farley-Hills 1971: 296). ${ }^{10}$ The name itself was widespread and popular in the area of Cheshire and southern Lancashire during the presumed period of composition of the Erkenwald poem. In his discussion of this subject, Peterson concluded that a John Massey of Cotton meets all the criteria that could identify him as the author of the Erkenwald text (Peterson 1977: 21). Massey can be connected with the House of Lancaster under John of Gaunt and Henry IV, as well as with Henry's son, who was the brother of the recipient of Hocceleve's poems mentioned above (Peterson 1977: 21). John Massey of Cotton died between 1409 and 1415, which would again agree with the presumed period of composition of the poem. The location of Cheshire would, furthermore, agree with the scribal language which indicates the area of Cheshire and Lancastershire as the presumed region of origin. ${ }^{11}$ Consequently, this would then connect the author with another associate of John of Gaunt, Geoffrey Chaucer, placing the story of St Erkenwald in the context of the most important author of this period and the ruling elite of England. ${ }^{12}$

There are only two capitals in the poem, one in the first line, the second in line 177, thus dividing the poem into two halves of 176 lines each. ${ }^{13}$ The capital in line 177 indicates the beginning of the dialogue between Bishop Erkenwald and the corpse of the judge. Other than the presence of these two capitals, the

10 Barbara Nolan (in Peterson 1977: 20) drew the connection between the same John of Massy and the Pearl poem which, however, were rejected by Peterson based on her incorrect methods.

11 It is commonly agreed that the language of St Erkenwald is that of the Northwest Midlands of England, see Horstmann (1881: 266) and Peterson (1977: 23). During the discussion about the language used in the manuscript of the Erkenwald poem, numerous arguments were made in favour of various northern dialects (Oakden 1930: 25). In spite of a possible connection with a northern area, there has not been any argument in the past to rule out Cheshire, or, more particularly, the northeast of Cheshire, as the area of origin of the poem; as of today, the poem is accepted to have been composed in the Northwest Midland dialect (Peterson 1977: 24).

12 In his discussion of the authorship of St Erkenwald, Peterson returns to a discussion of hints which connect the Pearl manuscript British Library Ms. Cotton Nero A. x. art. 3 with John of Massey; he also suggests a new basis to continue the discourse about a possible common author of both the Erkenwald and the Pearl-poems (Peterson 1977: 23). This discussion has not reached a shared consensus yet.

13 McAlindon further divided the poem claiming that the poet devoted not only 32 lines for the historical introduction but also 72 lines to the opening of the tomb underneath St Paul's Cathedral and 72 lines to Erkenwald himself (McAlindon 1970: 485). 
manuscript bears no indication of any further divisions, particularly no strophic divisions, which Carl Horstmann added to his edition..$^{14}$ Like Horstmann, Gollancz proposed a quatrain system, i.e. four-line stanzas, for the Erkenwald poem based on his discovery of markings in the manuscript of the Pearl-poems, particularly in Patience and Cleanness, indicating this stanza-system. This, however, was again based on the presumed common authorship and the similarities between these texts. Following the claim that there were different authors, the argument for the quatrain structure in the story of Erkenwald cannot be upheld (Peterson 1977: 28). The evidence of punctuation, too, proved inconclusive even though Savage and other editors added punctuation marks to their texts, indicating possible stanzas. Peterson concludes that a quatrain system might be imposed upon the poem, adding that this system could change, or presumably falsify the meaning of the text (Peterson 1977: 30). ${ }^{15}$ The original structuring of the poem, therefore, remains unknown.

A classification of the poem in terms of its meter and its alliterations seems less problematic. The poem of St Erkenwald can be assigned to the literary tradition of the so-called Alliterative Revival which took place during the Middle English period, particularly during the second half of the fourteenth and the beginning of the fifteenth century. It is based on the techniques of Old English poetry but shows some modifications and Continental influences (Peterson 1977: 30). ${ }^{16}$ As was mentioned before, connecting the poem of St Erkenwald with this tradition also agrees with the presumed date of composition.

In regard to the content of the poem, the story of St Erkenwald can be divided into three different parts. The first 32 lines form a historical introduction setting the place, London, and the time, England during the $7^{\text {th }}$ century, of the story (Gollancz 1922: xi-xxv). This part also outlines the immanent and past history of the story itself, placing the poem in a temporal setting. The second part provides the story itself, together with the conversation between Bishop Erkenwald and the corpse of the judge. The last 32 lines of the poem form an epilogue of the story (Peterson 1977: 26). In spite of the title, the story outlined in the poem is not part of the hagiographical corpus of texts about the bishop and saint. ${ }^{17}$ The first evidence about Erkenwald is found in Bede's Historia

14 On the discussion about possible strophic divisions common in Middle English poetry and their evidence in the Erkenwald poem, see Peterson (1977: 26-30).

15 The arguments against this form of structuring in the manuscript need to be kept in mind. However, the form used in Peterson's edition are kept in the following discussion of the relevant passages in this article for reasons of clarity. The same can be said of the presentation of these passages in four-line stanzas.

16 For a detailed discussion of the meter and the form of alliteration found in the poem, see Peterson (1977: 30-35).

17 The hagiographical works and the discussion about St Erkenwald himself is, therefore, set aside from the purpose of this discussion. For an introduction to the hagiographical history 
Ecclesiastica Gentis Anglorum, where Bede names Erkenwald as the newly appointed bishop of the East Saxons:

Tum etiam Orientalibus Saxonibus, quibus eo tempore praefuerunt Sebbi et Sigheri quorum supra meminimus, Earconualdum constituit episcopum in ciuitate Lundonia. Cuius uidelicet uiri, et in episcopatu, et ante episcopatum uita et conuersatio fertur fuisse sanctissima, sicut etiam nunc caelestium signa uirtutum indicio sunt. Etenim usque hodie feretrum eius caballarium, quo infirmus uehi solebat, seruatum a discipulis eius, multos febricitantes uel alio quolibet incommodo fessos, sanare non desistit. Non solum autem subpositi eidem feretro uel adpositi curantur aegroti, sed et astulae de illo abscissae atque ad infirmos adlatae citam illis solent adferre medellam.

(Bede, IV: 6$)^{18}$

Bede adds that Erkenwald also founded two monasteries, one at Chertsey and one at Barking in Essex, where Erkenwald's sister became an abbess. Erkenwald himself was made bishop of London in 675 or 676, less than a century after Augustine's arrival in England and the beginning of the Anglo-Saxon mission (Peterson 1977: 36). St Paul's Cathedral in London, the setting of the story as it is described by the poem, was built during the time of Bishop Mellitus, first bishop of London who died in $624 .{ }^{19}$ There is no reliable information about Erkenwald's death, which has been dated sometime between 685 and 693; he was buried in $\mathrm{St}$ Paul's Cathedral and reburied in a new shrine in 1140, and again in 1148 (Peterson 1977: 37-38). It was during this time in the mid-twelfth century that a number of his miracles were set down and added to an earlier vita about the bishop and saint. His cult continued at least into the fifteenth century and Erkenwald was later also brought into connection with a coat of arms indicating both his deeds as bishop of London as well as his presumable royal descent (Peterson 1977: 38).

of the saint, see Peterson (1977: 35-38, and 62-63). The fact that the story cannot be found in the hagiographical works about St Erkenwald led Sandra Cairns (1982: 431) to her claim that it is an invention by the poet.

18 "Sebbi and Sighere, already mentioned, were the reigning monarchs. Both before and after his consecration, Eorcenwold lived so holy a life that even now miracles bear witness to it. To this day the horse-litter in which he used to be carried when ill is preserved by his followers and continues to cure many people afflicted with fevers and other complaints. Not only are people cured who are placed in or near the litter but splinters cut from it and taken to the sick bring speedy relief" (McClure and Collins 1994: 186). The Latin text can be found in: Lapidge (2005: 232-234).

19 The poem puts Erkenwald's office in line with Augustine who, however, never appeared as bishop of London: see lines 33-36 in Peterson (1977: 73). The understanding of Mellitus as first bishop of London ignores all British pre-Augustine British bishops of the city. For the discussion about the connection between the reconstructions of St Paul's Cathedral under Erkenwald, see Peterson (1977: 36-38) as well as Otter (1994: 407). Later accounts claimed that Erkenwald was the son of an East Anglian king, Offa. This information, however, cannot be deduced from the earliest account found in Bede's Historia (Peterson 1977: 35). 
The hagiographical works about St Erkenwald do not mention any of the events described in the Middle English poem (Cairns 1982: 431). ${ }^{20}$ There is no historical source for the meeting of the bishop with the corpse of a righteous pagan judge buried underneath St Paul's Cathedral. ${ }^{21}$ In spite of its title, the poem's focus is not on St Erkenwald, but on the figure of the judge, whose corpse is discovered in a tomb during the reconstruction of the cathedral. This discovery is made during the absence of the bishop, who is visiting a monastery in Essex. The Londoners are not able to make sense of the inscriptions on the sarcophagus that holds the corpse of an unknown person. The visitors to the tomb are amazed because the body discovered is not only adorned with a crown and a sceptre but also looks as if it was buried only hours ago, wearing unharmed clothes and untouched by decay. After historians and learned men fail to find information about this unknown man, Erkenwald returns to the city and begins to resolve this miracle. After a night of prayer and meditation he visits the tomb and questions the corpse about his past. The corpse explains that he is a judge from pagan times who, after his death, received praise and gifts from the people of London for his duties and actions on behalf of the city. He tells Erkenwald about his righteousness and his services for his king and his city which explains his wearing a crown and the sceptre. In spite of the pious life of the man of the law, he is, of course, not allowed into heaven, since he was never baptized and never became a Christian. Consequently, he has spent all the years since his death in limbo. Bishop Erkenwald is moved by the explanations of the judge. In his lamenting for this good man who is refused salvation Erkenwald whispers the words of baptism. At the same time one of the bishop's tears falls down on the corpse, who thus receives the sacrament of baptism and is allowed to leave limbo and rest in salvation..$^{22}$ The poem closes with praise for God and his judgment, which is one of the main themes of the story (Benson 1965: 403).

In regard to the sources of this poem, there can hardly be any doubt about the influence of the story of Gregory the Great and Emperor Trajan (Peterson 1977: 38). ${ }^{23}$ The similarities between the Trajan story, which was used in a vari-

20 Since there is no direct connection between the hagiographical sources of the saint and the poem, further details of his life and miracles as well as of his later cult are not subject of this study. For an introduction to the Vita Sancti Erkenwaldi and The Miracula Sancti Erkenwald, see the most recent edition by E. Gordon Whatley in: Whatley (1989). For the discussion about the parallel of the corpse in the poem and of the unharmed corpse of the saint in his vitae, see Whatley (1986: 356-58).

21 Sandra Cairns (1982: 434) claimed the grave-wonder of the poem to be an allusion to the future events of Erkenwald's own grave during the $14^{\text {th }}$ century, i.e. the moving of his corpse in St Paul's Cathedral, and the fact that his tomb was not harmed by a fire in 1089 .

22 This form of baptising the judge in the poem caused William Kamowski to claim that the baptism was accidental (Kamowski 1995: 5).

23 This was also argued for in Kamowski (1995: 6) and Cairns (1982: 431). Thikms (2005: 
ety of medieval sources spread all over Europe, and the Erkenwald poem are obvious (Peterson 1977: 38-40). In both stories, a tomb of a just pagan is discovered by chance and the discovery upsets the witnesses and the people (Whatley 1986: 335). Both corpses receive salvation through the praise or the lament of a Churchman and are rewarded for their righteousness and piety. In addition to the parallels between the Erkenwald and the Trajan stories, there are a number of examples for corpses being saved by saints in medieval texts. There is, however, only one known parallel for the finding of an uncorrupted corpse, namely in John Bromyard's Summa Praedicantium, written during the first half of the fourteenth century (Wenzel 1981: 13). ${ }^{24}$

Aside of the influence of other legends, the Erkenwald poet also used a variety sources for his text (Kamowski 1995: 5). ${ }^{25}$ His treatment of the subject matter implies both deep historical background knowledge and an influence of events and developments of the $14^{\text {th }}$-century England. In regard to the major historical works the poet drew his information from, the familiarity of the Erkenwald poet with Geoffrey of Monmuth's Historia Regum Britanniae and with the liturgy of the Church is commonly agreed upon. It is also possible that he used Bede's Chronica Maior for his story (Peterson 1977: 45). ${ }^{26}$ This does, of course, not exclude other works of historiography the poet might have had access to and might have used. ${ }^{27}$ Furthermore, the call for commemoration of

311) even argued that the Trajan story is "transformed into" a $7^{\text {th }}$-century Erkenwald story. Allen Frantzen (1981: 158) claimed that the influence of the Trajan legend on Erkenwald was exaggerated by its scholarly discussion. The story of Trajan centres around the famous Roman emperor and the murdered son of a widow who begs him for justice against his murderer. Trajan leaves his forces to attend to the wish of the widow. Gregory the Great then passes the tomb of the emperor centuries later and is reminded of the story of the just pagan. He prays for the emperor's condemned soul and, in a dream, learns that his prayers were answered and Trajan's soul was saved.

24 Wenzel (1981: 13) argues for another possible example written before 1431. Frantzen questioned the parallels between the Erkenwald poem and the Trajan story based on the different treatment of baptism. In Trajan's story, baptism is not necessary for salvation whereas it is the only way to salvation in the story of Erkenwald. For the discussion about the contrast in both poems, see Frantzen (1981).

25 A variety of sources and traditions influencing the poem was also argued for by Siegfried Wenzel in: Wenzel (1981: 13) and Gollancz (1922: xxxiv-xxxviii).

26 For the discussion about the poet's use of the liturgy, see Peterson (1977: 45-51) and Whatley (1986: 359-60).

27 The poem demonstrates a certain historical knowledge of the poet. However, Cairn's optimism that "it is unlikely (and disproved by the historical introduction of the poem) that the poet himself was ignorant of the facts of Erkenwald's poem" seems rather strong when considering about 700 years of history which had passed between the Saint living in London and the poem being composed (Cairns 1982: 433). I do not see any of the facts of Erkenwald's life proved or disproved by the first lines of the poem, particularly because our knowledge of these presumed facts from this period are limited. 
St Erkenwald in 1386 by Braybrooke, Bishop of London, was argued to have contributed to the content of the poem, which shows the influence of events and developments of $14^{\text {th }}$-century England (Kamowski 1995: 8). ${ }^{28}$

\section{The English in the story of St Erkenwald}

As was mentioned before, the poem of St Erkenwald begins with what has been claimed to be a historical introduction (McAlindon 1970: 476).$^{29}$ The story is set in Erkenwald's diocese in London during the reconstruction of St Paul's Cathedral. The following passage indicates not only the interest of the poem in the history of the English, but also provides the audience with a sense of the island's pagan past: ${ }^{30}$

In his tyme in pat toun pe temple alder-grattyst Was drawen doun, pat one dole, to dedifie new, For hit hethen had bene in Hengyst dawes pat pe Saxones vnsazt haden sende hyder.

Pai bete oute pe Bretons, \& brozt hom in-to Wales And peruertyd alle pe pepul pat in pat place dwellide. ben wos this reame renaide mony ronke zeres

Til Saynt Austyn into Sandewiche was sende fro pe pope:

Den prechyd he here pe pure faythe and plantyd pe trouthe And conuertyd alle pe communnates to Cristendame newe. He turnyd temples pat tyme pat temyd to pe deuelle And clansyd hom in Cristes nome and kyrkes hom callid.

(Erkenwald, $11.5-16)^{31}$

28 In addition, Kamowski claimed an immediate relevance of the poem for $14^{\text {th }}$-century England as a reaction to the heresy inspired by John Wycliff and his criticism against ecclesiastical corruption and simony. The connection between the poem and the radical theology and angry criticism against the Church in $14^{\text {th }}$-century England was also made in: Whatley (1986: 345-46). Further scholarly discussions developed about the essential role of the Church in salvation, as demonstrated in the poem, see Morse (1975: 24-29) and Kamowski (1995: 8-11). The reading of the Erkenwald poem to glorify the role of the Church was criticized by Thikms, who argued the story to glorify God's grace through the sacrament of baptism instead (Thikms 2005: 311).

29 McAlindon claimed that the introduction, or the historical sketch, as he puts it, is used to provide a realistic environment for the narrative which, then, unfolds in a dramatic and not in a historiographic mode.

30 The following references, including the references to the line numbers, are all taken from the latest edition by Clifford Peterson. The translations of the Middle English lines are my own.

31 "In his time the greatest temple in the city / Was in part torn down to be dedicated new, / 
This passage informs the audience that London and the community is in a process of change. St Paul's Cathedral is being torn down and rebuilt to re-dedicate it to the Christian faith. The destruction and rebuilding of the cathedral was claimed earlier to indicate the break between the pagan past and the Christian present of the English, symbolized by the changes undertaken in the building. ${ }^{32}$ This reading is emphasized by the critical view of the pagan ruler who, according to the story, sent the Saxons to Britain. Aside from the descriptions of the battles against the Britons, this passage contains the poet's critical view of the invaders of Britain who "peruertyd alle pe pepul pat in pat place [i.e. Britain] dwellide". The poet is not only accusing the pagan Saxons of fighting the Britons but also of corrupting their Christian faith. This makes this passage interesting for two reasons: first, the poet demonstrates his knowledge of the pagan Saxons' invasion of Britain and their battles against a Christian people; his way of presenting this event demonstrates his standing on the Briton's side, not only accusing the invading people to have "peruertyd alle pe pepul" but also calling them "vnsazt", savages. In doing so, this part of the poem suggests the poet composing his text from the perspective of a historically learned Christian. The second interesting aspect in this passage is the use of the ethnonym Saxones. ${ }^{33}$ When introducing the invasion of Britain by a number of different peoples from the Continent, the poet chooses to include the Saxons only, remaining silent about other ethnic groups who participated in this event such as the Angles or the Jutes. Excluding the Angles, or English, from the arrival of the Germanic gentes in Britain, this passage follows the earliest historical source about this event, Gildas's De Excidio et Conquestu Britanniae. In doing so, the Erkenwald poet creates a significant distinction between the pagan invaders, to whom he refers as Saxones, and the English audience of his poem, thus silently disconnecting the Christian people of England from their pagan ancestors. So while

For it had been honored in the days of Hengest by heathen, / Who had sent the Saxon savages over./ They outbattled the Britons and drove them into Wales / And perverted all the people who lived in this place. / Then was this realm godless a long many years, / Until Augustine was sent to Sandwich by the Pope. / Then he preached there the pure faith and planted the truth / And converted the whole community to the Christian faith again./ He turned again the temples that were taken by the Devil / And cleansed them in Christ's name and called them churches."

32 This indicates the dialectic approach towards the past and the present in the poem as well as its meaning for the $14^{\text {th }}$-century audience who, throughout the poem, experienced the story as a reflection of their own past (Otter 1994: 390).

33 Arnold Davidson explained this passage as a contrast of the violent conquest by the Saxons with the peaceful conversion to Christianity centuries later (Davidson 1980: 40). While this contrast may be of importance to the poet, my reading focuses rather on what the poet is not saying, i.e. that he mentions the pagan Saxones without making a connection with their descendants, the English in Erkenwald's time or at the time of composition. 
this passage shows a conscious treatment of the historical past of Britain, it also demonstrates a very explicit choice when it comes to introducing the details of this past by the author.

The discovery of the unknown tomb during the construction work attracts the interest of the people passing the cathedral; learned and powerful men are called for counsel. The tomb is opened and the people find the corpse of a man in it, adorned with a crown and jewels, dressed in wealthy and wonderful clothing; the corpse does not show any sign of decay, and it seems as if it was put into the tomb only a short time ago. The discovery raises the question of the identity of this man, demonstrating the author's interest not only in the history of England but also in the collective memory of the English: the author calls it a "derfe wonder" that no one recognizes the corpse and no one can identify him or the regalia he was buried with:

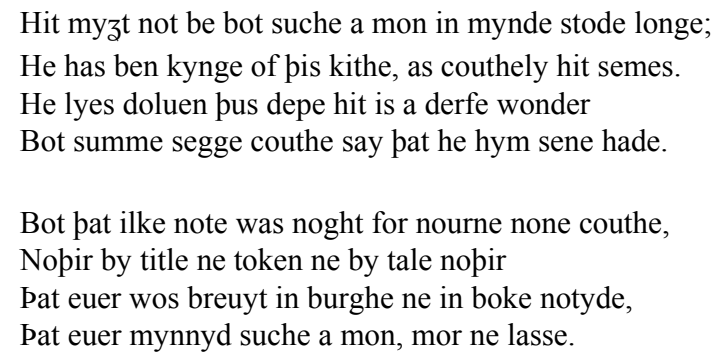

(Erkenwald, 11.97-104) $)^{34}$

The certainty that such a man would be remembered by the people underlines the relevance of a collective memory for the audience of this scene; the people of London would expect a man of such obvious importance to be remembered in their community and are confused when learning that this is not the case. This passage indicates the important role of a collective memory and of historical knowledge the poet expresses in his text; similar to the previous passage, where the English were excluded from the invasion of Britain at the beginning of the Middle Ages, this passage silently excludes the corpse, of whom the audience has no information yet, from the collective memory of the English. By doing so, the author creates a separation between the people of Erkenwald's London and their time and the person discovered in the tomb. This separation is strengthened in the following passage.

34 "A man like this would surely be long kept in mind; / It seems clear enough that he was a king in this country, / Since he lies buried here so deep it would be a great wonder / If we cannot find someone who could say he has seen him. / But he remained unknown because no one could name him / Neither by title or token or ancient tale / There never was a man seen in that city or noted in the books / Who had ever heard of such a man, highborn or low." 
The mysterious origin of the man causes increasing irritation among the people of London. Since the runes adorning his tomb are unknown to the gathering audience, learned men are employed in the search for information about the mysterious corpse:

And we haue oure librarie laitid pes longe seuen dayes

Bot one cronicle of pis kynge con we neuer fynde.

He has non layne here so longe, to loke hit by kynde,

To malte so out of memorie, bot meruayle hit were.

(Erkenwald, $11.155-158)^{35}$

Unable to find information about the corpse or the tomb in their collective memory, the curious audience of the scene turns to the learned men, libraries and the study of an unspecified chronicle to find information about this man. ${ }^{36}$ The role of the historical research is of interest in this part: Erkenwald became bishop of London around 675 and remained in his office until his death between 685 and 693. As mentioned above, he was the fourth bishop of London and received his office approximately 70 years after Mellitus became the first bishop of the city. This is a rather short time span of episcopal history in London, which can be researched for information about the unknown corpse. In addition, the mission of Augustine in England began only about ten years before Mellitus became bishop, which means that the Christian tradition and the Christian history of the English cannot have been older than 95 years when the body was discovered. The interest in and the effort put into the historical research by the people of London surprises in regard to less than 100 years of English Christian history, and presumably only little more than 250 years of English presence in Britain altogether. This indicates that, apart from historiographic details, it is also the concept of history that is of interest to the poet. ${ }^{37}$ I will return to the role and use of history in the poem in my conclusion.

The audience of the poem learns that neither the chronicles nor the learned men of London can provide information about the identity of the corpse. After

35 "And we have searched our libraries these seven long days / But could not uncover a single chronicle of this king. / He has not lain here too long, from the looks of him, / To have melted so out of our mind - but were it by a miracle."

36 Consulting books in order to identify the discovered corpse is another parallel between the Erkenwald poem and the Trajan legend, see Whatley (1986: 335). In spite of the fruitless effort of their historical research, I do not share Sandra Cairn's reading of this passage as to demonstrate the audience's futility of "trying to find documentary evidence" instead of simply accepting "the might and mercy of God" to solve the present questions (Cairns 1982: 437). In contrast, I read this passage as an expression of interest in and the presence of historical knowledge.

37 However, I would refrain from understanding the reference to the chronicle as indication for the poem's basis on historical facts as was claimed in: Cairns (1982: 435). 
the previous passage informed the reader that the unknown man in the tomb could not be identified through the knowledge of the audience's collective memory, this passage excludes him from the known albeit young history of the English. The people of London, therefore, send for Erkenwald to solve the miracle of the unharmed corpse. ${ }^{38}$ The returning bishop calms down the upset crowd. Finally, Erkenwald questions the corpse himself about his identity, and he answers him willingly:

Fyrst to say the pe sothe quo my selfe were-:

One be vnhapnest hathel pat euer on erthe zode.

Neuer kynge ne cayser ne zet no knyzt nothyre,

Bot a lede of pe laghe pat pen pis londe vsit.

I was committid and made a mayster-mon here

To sytte vpon sayd causes, pis cite I zemyd

Vnder a prince of parage of paynymes laghe,

And vche segge pat him sewide pe same faythe trowid.

pe lengthe of my lyinge here, pat is a lewid date

Hit is to meche to any mon to make of a nommbre:

After pat Brutus pis burghe had buggid on fyrste,

$\mathrm{Noz}_{\mathrm{t}}$ bot fife hundred zere per aghtene wontyd

Before pat kynned zour Criste by Cristen acounte

A pre hundred zere and pritty mo and zet threnen aght.

I was of heire and of an oyer in pe New Troie

In pe regne of pe riche kynge pat rewlit vs pen,

The bolde Breton Ser Belyn, Ser Berynga was his brothire.

Mony one was pe busmare boden hom bitwene

For hor wrakeful werre quil hor wrathe lastyd.

ben was I iuge here enioynyd in gentil lawe.

$(\text { Erkenwald, 11.197-216) })^{39}$

38 For a discussion of the poem's change of mood at the arrival of Erkenwald see Davidson (1980: 41-42). It was claimed that the poem indicates that Erkenwald was visiting the monastery of his sister in Essex (Cairns 1982: 432).

39 "First I will tell the truth about what I was: / One of the most unlucky mortals ever moved on earth, / Never king nor kaiser yet no knight either, / But a judge of the law which this land then used. / I was commissioned and made a master here / To sit over these causes, in this city I ruled / By pagan law under a prince of high rank, / And all who attended his side avowed the same faith. / The length of the time I've lain here that is an unknown time; / It is too much for any mortal to grasp in his mind: / After Brutus had first founded this city, / It was nearly five hundred years - lacking eighteen - / Before the time when Christ was born, by Christian account; / From the time of my death, it was three hundred fifty-four years. / At that time I was justice of the Iter in New Troy, / In the reign of the noble king that ruled 
After neither the collective memory nor the history of the English were able to provide information about this man, he is allowed to tell his story himself. This passage not only provides this story, it demonstrates how the Erkenwald poem treats and makes use of history. First, there is a reference to the office of the cayser, which is, of course, a later influence on the subject matter; this office did not exist during the seventh century in Britain and can be seen as an influence on the poem from the time of its composition. Second, the judge provides a reference to a pagan law as well as to Brutus as the founder of London. Both of these references indicate the influence of Geoffrey of Monmouth's work, presumably also of the $9^{\text {th }}$ century Historia Britonum, which both contain accounts of Brutus as the founder of London. This establishes a direct connection between the people of Erkenwald's diocese and the British antecedents in the city of the early Middle Ages. Third, the judge provides information about the Britain of his time when he refers to the reign of the British King Belin, brother of Sir Brennin, both names are found in the king lists of Geoffrey of Monmouth. ${ }^{40}$ The judge claims he died in $354 \mathrm{BC}$, which would agree with the information provided by Geoffrey of Monmouth about the ascent of the two brothers in $387 \mathrm{BC}$. This passage, therefore, demonstrates the influence of two British texts on the story of St Erkenwald, and that the poet placed the office of the judge carefully in the context of the historical accounts that were known during the time of composition.

Similar to the poem itself, the story of the judge also begins with a historical introduction of his life. After placing his office in this historical context, he continues with his explanation for the crown and the sceptre he was buried with and tells Erkenwald about the details of his work:

For pe honour of myn honeste of heghest enprise

pai coronyd me pe kidde kynge of kene iusteses

us then, / The bold Briton, Sir Belin: Sir Brennin was his brother, / Many one were the angry insults between them, / for their ruinous wars while their wrath lasted. Then I was a judge here of the Gentiles' law." There have been different readings of lines 207-210. For the discussion about the time periods mentioned in this passage, the different calculations made by Horstmann, Gollancz and Savage and an alternative provided by ${ }^{37}$ However, I would refrain from understanding the reference to the chronicle as indication for the poem's basis on historical facts as was claimed in: Cairns (1982: 435).

40 Geoffrey of Monmouth, Historia Regum Britanniae, Book III, Chapter 1. The chapter introduces the two brothers as successors of the British King Dunwallo around BC 387. Immediately after the death of the king the brothers begin a raging civil war which is subsequently ended by amici, their friends who restore peace and divide the kingdom between them. A treaty is drawn and signed but, following the account of Geoffrey, the peace only holds for five years before the war begins again. Brennius is defeated by Belinus during the battle of Calaterium who then becomes King of Britain. 
Per euer was tronyd in Troye, opir trowid euer shulde, And for I rewardid euer rizt pai raght me the septre.

$(\text { Erkenwald, 11.253-256) })^{41}$

The emphasis on his honest and renowned work during his period of office is used as an indication of his righteous behaviour, which is essential for Erkenwald's understanding of and pity for the judge's situation. The judge's honesty and wisdom provide the foundation for his following baptism by the Bishop as a pious and righteous pagan. Erkenwald continues to investigate the judge's burial, trying to understand the curious state of the tomb. Erkenwald asks about the circumstances of the burial and the reason for both the tomb's and the corpse's lack of decay and whether the judge was embalmed before being buried, inviting the judge to further explain the good deeds and pious behaviour of his lifetime:

\footnotetext{
'Nay bisshop,' quop pat body, 'enbawmyd wos I neuer Ne no monnes counselle my clothe has kepyd vnwemmyd Bot pe riche kynge of reson pat rizt euer alowes And loues al pe lawes lely pat longen to trouthe.

And moste he menskes men for mynnynge of riztes

pen for al pe meritorie medes pat men on molde vsen;

And if renkes for rizt pus me arayed has

He has lant me to lad pat loues ryzt best'.
}

$(\text { Erkenwald, } 11.265-272)^{42}$

This passage introduces the central theme of the story of St Erkenwald, the problem of the righteous pagan who is refused salvation. He claims that God honours the righteous and the virtuous men. Salvation, however, is impossible for the judge, since he was no Christian (Frantzen 1981: 158). This explains his miserable state of existence:

Pen hummyd he pat per lay and his hedde waggyd,

And gefe a gronynge ful grete and to Godde sayde:

\footnotetext{
41 "For in honour of my honesty in highest praise / They crowned me the king of all the wise justices / That were ever enthroned in Troy or, they thought, ever should, / And for I rewarded every right, they granted me the scepter."

42 “"No bishop', the body said, 'I was never embalmed, / Nor could any man's knowledge ever have kept my clothes / But the all-knowing Lord, who always esteemed the righteous, / And loves all the lawful who long for truth. / And most he honors men for remembering the justice / More than for all other praiseworthy deeds men carry out on earth; / And if mortals arranged me thus for my righteousness, / He that loves honesty most allowed me to last."”
} 
'Mazty maker of men, thi myghtes are grete-

How myzt pi mercy to me amounte any tyme?

Nas I a paynym vnpreste, bat neuer thi plite knewe,

$\mathrm{Ne}$ pe mesure of pi mercy, ne pi mecul vertue,

Bot ay a freke faitheles pat faylid pi laghes

pat euer pou Lord wos louyd in? -Allas, pe harde stoundes'!

(Erkenwald, 11.281-288) $)^{43}$

As was stated above, the information about the judge can neither be found in the collective memory of the English nor in their history, which is no surprise since he turns out to be much older than anticipated. From these passages we can learn that he himself is a victim of history and that he was born a "freke faitheles pat faylid pi laghes", who had not been able to receive God's mercy. It becomes clear that even though the judge lived a pious and righteous life, his present state is merely the result of being a "paynym vnpreste" who was denied salvation because he never had the possibility to become a Christian. The judge continues to lament his being born too early to receive the Christian faith and, ultimately, salvation:

$z^{e}$ were entouchid wyt his tethe and toke in pe glotte

Bot mendyd wyt a medecyn zare made for to lyuye

Pat is, fulloght in fonte, wyt faitheful bileue,

And pat han we myste alle merciles, myselfe and my soule.

Quat wan we wyt oure wele-dede pat wroghtyn ay rizt,

Quen we are dampnyd dulfully into pe depe lake

And exiled fro pat soper so, pat solempne fest

ber richely hit arne refetyd pat after right hungride?

$(\text { Erkenwald, 11.297-301) })^{44}$

43 "Then he that lay there moaned and turned his head away, / And made a great groan and said to God: / 'Mighty Maker of men, Your might is great! / How might Your mercy ever reach toward me? / Was I not an Unknowing pagan, that never knew of Your pledge, / Nor of Your mercy or Your great virtues, / But always a Faithless person that lacked Your laws / That You were always believed in, Lord? Alas, the time is long!'”

44 "We were poisoned from his teeth, and took in the phlegm / But mended by medicine You made man may live, / That is the baptism by the font, with faithful belief, / And that we have missed mercilessly, myself and my soul. / What we won for our good deeds, who loved righteousness, / When we are damned, sorrowfully down into the deep lake, / And exiled from that supper, that solemn feast, / Where rich men are restored who hungered after righteousness?" 
This passage not only summarizes the judge's curious state of existence but also points out one of the main topoi of the poem - the righteous pagan who is refused salvation not because of sin but because of him missing the possibility to become Christian. His pitiable state is resolved by St Erkenwald's praising of his righteous and virtuous life. The Bishop is moved to tears and, when muttering the words of baptism, a tear falls down on the judge and he finally receives salvation and is allowed to leave limbo and find rest.

\section{Conclusion}

In the past, the focus of the scholarly discussion on the poem has always been directed at the role and the function of the judge's baptism. It is not my intention to cast doubt on this discussion. However, as I have argued in this paper, it is justified to say that there is more to the historical setting of St Erkenwald than has yet been acknowledged. There can be no doubt that the subject of the righteous but unbaptized heathen was an important topic in the theological debate of the $14^{\text {th }}$ century (Kamowski 1995: 9). The conversation between Bishop Erkenwald and the pagan judge also symbolizes an explicit encounter of London's present in the $14^{\text {th }}$ century with the British pagan past of the country (Otter 1994: 391) ${ }^{45}$

The discussion of exemplary passages of the St Erkenwald poem has demonstrated three particular aspects of the text. First, the poem indicates the important role of the collective memory of the people of London although it fails to provide information about the unknown man in the tomb. Second, history has a very prominent role in the Middle English poem; it contains numerous references to the history of the people of London as well as a reference to learned men, possibly historians, and a reference to an unknown chronicle. In addition, the judge localizes his own life in a historical context, presumably based on information drawn from Geoffrey of Monmouth or the anonymous Historia Brittonum. Third, the poem's treatment of history provides numerous indications about the way the protagonist and the bishop's audience described in the poem deal with their own history and, ultimately, with the past of their ancestors. ${ }^{46}$ The poem depicts how the protagonist and the bishop's audience deal with their own history and, ultimately, with the past of their own ancestors, indicating the relevance for and the treatment of history in the poem.

\footnotetext{
45 The same can be said about the construction work at St Paul's Cathedral in the poem which also connects the present of the poem's story with the past (Otter 1994: 408).

46 The importance of history for the poet was also stressed in: Cairns (1982: 431). On the sense of audience in Erkenwald, see Chism (2002). Monika Otter (1994: 414) argued for a specific understanding of the historical layering of the poem, acknowledging that medieval writing is capable of an imaginative and self-aware sense of the past.
} 
In regard to the function of the collective memory of the English as expressed in the poem, it is used as an element of exclusion. The poem emphasizes its existence and its importance for the audience of the scene depicted in the story; the judge, however, cannot be identified with the knowledge preserved in the collective memory and is consequently excluded from the people of Erkenwald's London. This exclusion creates an important distinction between the judge, a pagan Briton, and the English in the poem. The references to the collective memory of the English create, furthermore, the concept of a unified community in Erkenwald's London with a specific relationship to its shared memory and past.

Exclusion as well as the two concepts of continuity and discontinuity are also the three main aspects of the historical elements in the poem. The historical introduction of the poem first creates an explicit distinction between the "hethen Saxones vnsazt", the heathen Saxon savages, and the Christian Britons who are invaded, distinguishing the invaders and the invaded based on their different ethnicity and religion. Second, this particular passage also distinguishes the Saxons from the English, who do not appear at all in this historical introduction. ${ }^{47}$ The pagan Saxons are, therefore, carefully separated from the people in Erkenwald's diocese when the story takes place. While criticizing the Saxons for their invasion, the poem remains silent about the ancestors of the English. ${ }^{48}$ In addition, the difference between the history of the English and the history of the Britons becomes obvious in these passages: the text provides information about an early history of the Britons, voiced through the judge, presumably drawing from information of historical texts which were available to the author. So while the Saxons are excluded from an English past, disconnecting the Germanic invasion of Britain from the English in the poem, the history of the judge connects the Briton's past with the present of Erkenwald's diocese in London. The poem, therefore, creates an English, or, more specific, a London past through the story of the judge, not through the historical introduction in the beginning of the poem. The historical construction of the story of St Erkenwald thus connects the English with their British antecedents rather than with their Germanic ancestors.

This leads to the question why the poem disconnects the English people of Erkenwald's London from their pagan ancestors who invaded Britain centuries

\footnotetext{
47 In this, the poem provides information which reminds the reader of similar passages in Gildas's De Excidio et Conquestu Britanniae or in Bede's Historia Ecclesiastica Gentis Anglorum (Schustereder 2013: 285-286).

48 This missing connection between the English and their pagan ancestors was explained by Otter (1994: 396) with the disruption caused in English history by the Viking raids, emphasizing a painful sense of the past.
} 
earlier, while establishing a connection with a pagan British judge buried in London. The previous discussion indicates that the writing of an English history remained a challenge for authors in the late fourteenth and early fifteenth century when writing about the heathen past of the English. ${ }^{49}$ In this regard, the Erkenwald poem shows an explicit agenda in his dealing with the pagan past of the English: instead of establishing a historical connection between the English of Erkenwald's London with their ancestors who invaded the island centuries earlier, the author establishes a connection with the British antecedents of London. Although the ancestors as well as the antecedents were pagan, the story distinguishes both groups from each other, marking the Saxons as savages and connecting the English with the righteous British judge. In doing so, the poem creates two different registers of pagans and, ultimately, positions the English in a historical context with the righteous and noble pagan of British origin while disconnecting the people of Erkenwald's London from their Germanic ancestors who are condemned as savages who perverted the Christian Britons.

The use of history in the story of St Erkenwald distinguishes the English from their pagan ancestors and connects them with their pagan antecedents in Britain; the poem can, therefore, be seen within a medieval literary discourse contributing to a collective identity by creating a shared mythological, ethnic and religious origin. ${ }^{50}$ This discourse resulted from continuous political and social change throughout the Middle Ages in Britain including migration, invasion and colonization of geographical space and political entities. Such developments in return made the continuous construction of a shared history and origin of all of Britain's communities necessary.

In this regard, the discussion about the presumed authorship of the Erkenwald poem positions the story in the context of social and political developments of late $14^{\text {th }}$ - and early $15^{\text {th }}$-century England. As the previous discussion of the story demonstrated, the text is not at all free from influences from the time of its composition. It contains a reference to the cayser, an office which the late $14^{\text {th }}$ or early $15^{\text {th }}$ century audience of the poem must have been familiar with, but which did not exist yet during the lifetime of Bishop Erkenwald. Also, the celebrations of Erkenwald's office in 1383 possibly contributed to the composition of the text. There can be no doubt that the poem has a markedly London, which has been pointed out by the more recent research, where it was also argued to communicate a specific national character (Kamowski 1995: 8). This

\footnotetext{
49 The poet's focus on the pagan history of the English, the reign of Hengist and the role of the Augustinian mission was also brought up by Thomas McAlindon. However, this focus on the literary traditions of the story resulted in a neglect of its historical and mythological characteristics (McAlindon 1970: 476).

50 On the discourse of identity construction in literature from medieval Britain, see Schustereder (2013).
} 
claim is supported by the poem's perspective on a particularly English setting, albeit not an English history. In this context, the Erkenwald poem might well be seen to participate in the renewed writing of a particularly English history and tradition during this period, overcoming the influences resulting from the Norman Conquest which began to decrease during the presumed date of composition of the poem.

The discussion about the authorship of the poem adds another aspect to the poem's political agenda. While I remain sceptical about the identification of the Erkenwald poet with the author of the Pearl-group, there can be hardly any doubt that the author of the story of St Erkenwald was writing within a lively tradition of his time, employing motifs and elements of which it can be assumed were identified and received by his audience. The assumed connection between the text and John Massey of Cotton as a retainer of the Lancasters under John of Gaunt and Henry IV presents some interesting consequences in regard to the use and the importance of the poem's historical approach. If the Erkenwald poem can really be connected with John Massey of Cotton, this would indicate the familiarity of the ruling elites of medieval England with these motifs and themes of the poem, including the problem of connecting England and the English with their pagan past nearly one millennium after the arrival of their ancestors on the island. ${ }^{51}$

The story of St Erkenwald indicates that the discourse of writing a history of the English in general, and coming to terms with their pagan past in particular, was still active and a subject of interest among the social elites of the late fourteenth and early fifteenth century. The Erkenwald poem represents an example of this discourse in English literature demonstrating that the English and their pagan past remained a rather difficult motif for their authors throughout the English Middle Ages.

\section{REFERENCES}

Benson, Larry D. 1965. The authorship of St. Erkenwald. Journal of English and Germanic Philology 64. 393-405.

Cairns, Sandra. 1982. Fact and fiction in the Middle English De Erkenwaldo. Neuphilologische Mitteilungen 83. 430-438.

51 This would also agree with the argument brought forward by McAlindon who claimed that the poem had an aristocratic bias based on his reading of qualitative terms such as riche, noble and manerly (McAlindon 1970: 492) 
Chism, Christine. 2002. Alliterative revivals. Philadelphia: University of Pennsylvania Press.

Davidson, Arnold E. 1980. Mystery, miracle and meaning in Saint Erkenwald. Papers on Language and Literature 16. 37-44.

Frantzen, Allen J. 1981. Saint Erkenwald and the raising of Lazarus. Mediaevalia 7. 157-171.

Gollancz, Israel (ed.). 1922. St. Erkenwald. Oxford: Oxford University Press.

Horstmann, Carl (ed.). 1881. Altenglische Legenden: Neue Folge. Heilbronn: Verlag von Gebr. Henniger.

Kamowski, William. 1995. Saint Erkenwald and the inadvertent baptism: An orthodox response to heterodox ecclesiology. Religion and Literature 27. 5-27.

Lapidge, Michael (ed.). 2005. Histoire ecclésiastique du peuple anglais / 2 (Livres III - IIII). Paris: Les Éditions du Cerf.

McAlindon, T. 1970. Hagiography into art: A study of St. Erkenwald. Studies in Philology 67. 472-494.

McClure, Roger, Judith Collins. 1994. Bede. The ecclesiastical history of the English people. Oxford: Oxford University Press.

Morse, Ruth (ed.). 1975. St Erkenwald. Cambridge: D.S. Brewer.

Nolan, Barbara \& David Farley-Hills. 1971. The authorship of Pearl: Two notes. Review of English Studies XXII. 87. 295-300.

Oakden, James Parker. 1930. Alliterative poetry in Middle English. Manchester: University of Manchester Press.

Otter, Monika. 1994. 'New werke': St. Erkenwald, St. Albans, and the medieval sense of the past. Journal of Medieval and Renaissance Studies 24(3). 387-414.

Peterson, Clifford. 1974. Pearl and St Erkenwald. Some evidence for authorship. Review of English Studies 97. 49-53.

Peterson, Clifford (ed.). 1977. Saint Erkenwald. Philadelphia: University of Pennsylvania Press.

Savage, Henry L. (ed.). 1926. St. Erkenwald. New Haven: Yale University Press [u.a.].

Schustereder, Stefan. 2013. Strategies of identity construction. The writings of Gildas, Aneirin and Bede. Bonn: Bonn University Press.

Thikms, A. 2005. The sacrament of baptism in St. Erkenwald: The perfect transformation of the Trajan legend. Neophilologus 83. 311-327.

Wenzel, Siegfried. 1981. St. Erkenwald and the uncorrupted body. Notes and Queries 28(1). 1314.

Whatley, Gordon. 1986. Heathens and saints: St. Erkenwald and its legendary context. Speculum 61(2). 330-363.

Whatley, Gordon (ed.). 1989. The saint of London. The life and miracles of St.Erkenwald. Binghampton, N.Y.: Medieval \& Renaissance Texts \& Studies. 